\title{
Testosterone Level in Testicular Cancer Patients after Chemotherapy
}

\author{
M Sarfraz ${ }^{1}$, Y Ashraf $^{2}$, S Sajid ${ }^{1}$, MA Ashraf ${ }^{3}$
}

\begin{abstract}
Background: The use of chemotherapy for the treatment of cancer began at the start of the $20^{\text {th }}$ century in an attempt to narrow the universe of chemicals that affect the disease. Metastatic testicular cancer has always been sensitive to chemotherapy.

Subjects and Method: A retrospective and prospective study was performed of patients who had undergone testicular cancer from 2011-2013. The overall age of the testicular cancer patients at the time of diagnosis, their marital status, stage of disease and treatment strategies, testosterone level etc were analysed using linear regression and $\mathrm{t}$-test.

Results: Most of the patients had seminoma tumour. A greater number of patients were diagnosed in the later stages of the disease. Before chemotherapy, testosterone level was normal and decreased during chemotherapy but after completion, it returned to normal level.

Conclusion: There is an early onset of testicular cancer in the Pakistani population. There is no effect of chemotherapy on testosterone production in late survivors.
\end{abstract}

Keywords: Testicular cancer, chemotherapy, testosterone, tumour

\section{Nivel de Testosterona en Pacientes con Cáncer Testicular después de la Quimioterapia}

\author{
M Sarfraz ${ }^{1}$, Y Ashraf $^{2}$, S Sajid ${ }^{1}$, MA Ashraf ${ }^{3}$
}

\begin{abstract}
RESUMEN
Antecedentes: El uso de la quimioterapia para el tratamiento del cáncer comenzó a principios del siglo $X X$, en un intento por reducir el universo de productos químicos que afectan la enfermedad. El cáncer testicular metastásico ha sido siempre sensible a la quimioterapia.

Sujetos y método: Se realizó un estudio retrospectivo y prospectivo de pacientes que habían sufrido cáncer testicular en el período 2011-2013. La edad general de los pacientes de cáncer testicular en el momento del diagnóstico, su estado civil, etapa de la enfermedad y tratamiento, estrategias de nivel testosterona, etc. se analizaron mediante regresión lineal y prueba $t$.

Resultados: La mayoría de los pacientes tenían tumores seminomas. Un mayor número de pacientes fue diagnosticado en las etapas avanzadas de la enfermedad. Antes de la quimioterapia, el nivel de testosterona fue normal y disminuyó durante la quimioterapia, pero una vez terminada, volvió al nivel normal. Conclusión: Hay un inicio temprano del cáncer testicular en la población paquistaní. No hay efecto de la quimioterapia sobre la producción de testosterona en los supervivientes tardios.
\end{abstract}

Palabras claves: Cáncer testicular, testosterona, quimioterapia, tumor

West Indian Med J 2015; 64 (5): 487

From: 'Institute of Pharmacy, Physiology and Pharmacology, University of Agriculture, Faisalabad, Pakistan, ${ }^{2}$ Department of Zoology, University of Punjab, Lahore, Pakistan and ${ }^{3}$ Universiti Malaysia Sabah, Kota Kinabalu, Sabah, Malaysia.

Correspondence: M Sarfraz, Institute of Pharmacy Physiology and Pharmacology, University of Agriculture, Faisalabad, Pakistan. E-mail: maliha. sarfraz@yahoo.com

\section{INTRODUCTION}

Testicular cancer is an abnormal growth of cells in the testicles. It is most common in men 15 to 35 years old (1). More than 95 per cent of all men survive the disease $(2,3)$. For the diagnosis of disease, the International Germ Cell Cancer Collaborative Group (IGCCCG) classification is currently used in clinical practice (4). It is hypothesized that the disease process 
starts in fetal life and consists of abnormal proliferation of primordial germ cells $(1,5)$ and peak incidence is in the younger age groups, but the majority is seen in the third decade (6). Different risk factors such as reduced feedback inhibition of the gonadal-hypothalamic-pituitary axis, testicular atrophy and injury, increased gonadotrophin decline and cryptorchidism are involved in the development of a testicular tumour $(7,8)$. Low parity is considered a stronger risk factor for testicular cancer (9). Surgery, radiation therapy and chemotherapy are the treatment for this disease (10). Anticancer drugs are recommended when there are signs that the cancer has spread. Bleomycin, etoposide and cisplatin are the standard treatment for testicular germ cell cancer patients (11). Blood components will decrease after chemotherapy, but at different speeds (12). Testicular cancer affects mostly young people; they can survive after treatment, but they may experience negative impacts on their quality of life, such as hormonal disturbances (12). The aim of the present study was to investigate the effects of chemotherapy on testosterone levels in testicular cancer patients. The hormone levels affected due to chemotherapy were differentiated from the effects of the tumour itself by comparing the hormone levels before the onset of chemotherapy to levels measured during and after completion of chemotherapy.

\section{SUBJECTS AND METHODS}

This was a prospective and retrospective study of men with testicular cancer, conducted during 2011-2013. The study was carried out in the Nuclear Medicine, Oncology and Radiotherapy Institute (NORI), Islamabad, and Combined Military Hospital (CMH), Rawalpindi. The study evaluated one hundred patients with histologically proven testicular cancer. Of these patients, seventy-five were diagnosed during the period of 2011-2013, while thirty previously diagnosed cases were also included in the present study.

For the estimation of testosterone, $3 \mathrm{~mL}$ of venous blood from each subject was collected then allowed to clot at room temperature. After clotting, blood was centrifuged at $3000 \mathrm{rpm}$ (revolutions per minute) for 10 minutes. The serum was then separated in labelled tubes and frozen at $-20{ }^{\circ} \mathrm{C}$ for the estimation of testosterone. Testosterone EIA test kit (BioCheck Inc, CA, USA), catalogue number BC-1115, was used to determine testosterone concentrations.

\section{Statistical analysis}

Percentage, mean, standard error of mean, linear regression, and $t$-test for percentages were calculated for different parameters. Graph Pad version 5 was used for statistical analysis.

\section{RESULTS}

This study is based on data from 100 patients diagnosed with testicular tumour. The age group of testicular cancer patients at the time of diagnosis is shown in Table 1. Patients were divided into six age groups, with an interval of 10 years. Majority of the patients were between the ages of 21 and 30 years $(\mathrm{n}=38 ; 38 \%)$ with a mean age of $25.68 \pm 0.47$ years.

The mean age of married and unmarried patients is shown in Table 1. In the age group of 21-30 years, there were significantly more unmarried patients $(p<0.04)$ as compared to married patients.

The types of testicular tumour in married and unmarried patients in different age groups are shown in Table 2. In the age group of 21-30 years, the highest number was unmarried patients $(16.90 \%)$ with seminoma tumour, while the lowest number of patients $(1.41 \%)$ was observed with teratoma. All the patients were married in the age groups of 31-40 and 4150 years. The highest percentage of married patients $(18.31 \%)$ was observed with seminoma tumour and the lowest number of patients $(1.41 \%)$ was observed with mixed germ cell tumour at $31-40$ years, while $11.26 \%$ of patients with seminoma and $1.41 \%$ patients with embryonal carcinoma were observed in the age group of $41-50$ years.

The majority of patients $(63.89 \%)$ having a child was diagnosed with seminoma tumour, but the lowest number $(2.77 \%)$ of these patients was observed with yolk sac tumour. The majority of patients $(61.11 \%)$ having no children was diagnosed with seminoma tumour, but the lowest number (11.11\%) of patients was observed with teratoma and embryonal carcinoma (Fig. 1).

Table 1: Mean age (years) and percentages of testicular tumour patients according to different age groups and marital status

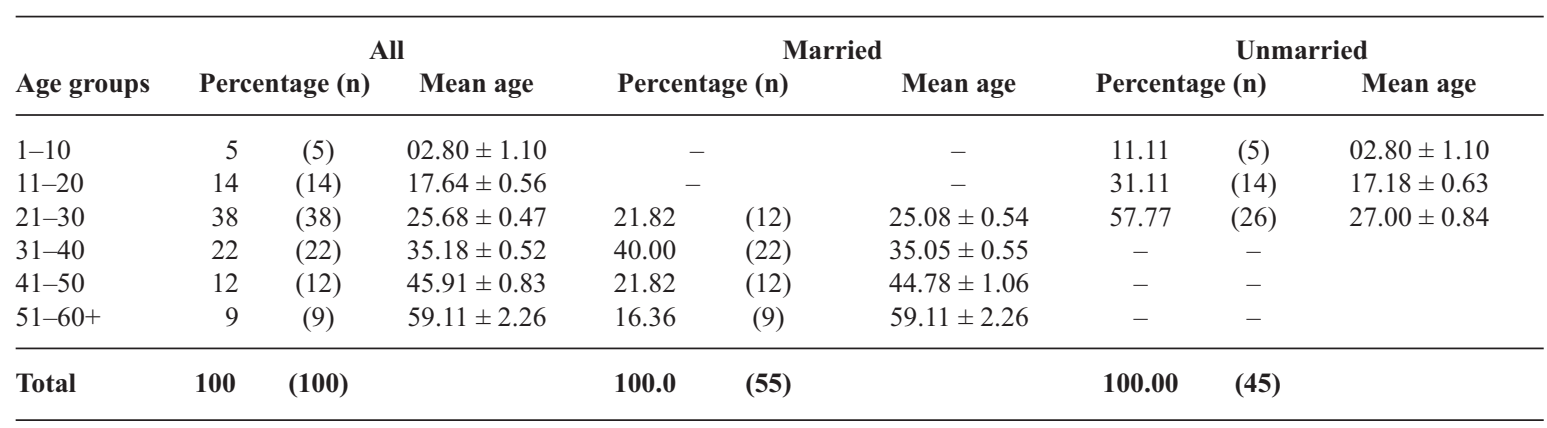


Table 2: Percentage of married and unmarried patients according to different age groups (years) with different types of testicular tumour

\begin{tabular}{|c|c|c|c|c|c|c|}
\hline \multirow[t]{2}{*}{ Diagnosis } & \multicolumn{3}{|c|}{ Married (Age groups) } & \multicolumn{3}{|c|}{ Unmarried (Age groups) } \\
\hline & $\begin{array}{c}21-30 \\
\text { (n) }\end{array}$ & $\begin{array}{l}31-40 \\
\text { (n) }\end{array}$ & $\begin{array}{c}41-50 \\
\text { (n) }\end{array}$ & $\begin{array}{c}21-30 \\
\text { (n) }\end{array}$ & $\begin{array}{c}31-40 \\
\text { (n) }\end{array}$ & $\begin{array}{c}41-50 \\
\text { (n) }\end{array}$ \\
\hline Seminoma & $\begin{array}{l}8.45 \% \\
(6)\end{array}$ & $\begin{array}{c}18.31 \% \\
(13)\end{array}$ & $\begin{array}{c}11.26 \% \\
(8)\end{array}$ & $\begin{array}{c}16.90 \% \\
(12)\end{array}$ & - & - \\
\hline Mixed germ cell tumour & $\begin{array}{c}7.04 \% \\
(5)\end{array}$ & $\begin{array}{l}01.41 \% \\
(1)\end{array}$ & $\begin{array}{l}02.82 \% \\
\text { (2) }\end{array}$ & $\begin{array}{c}11.26 \% \\
(8)\end{array}$ & - & - \\
\hline Embryonal carcinoma & - & $\begin{array}{l}04.22 \% \\
\text { (3) }\end{array}$ & $\begin{array}{l}01.41 \% \\
\text { (1) }\end{array}$ & $\begin{array}{c}04.22 \% \\
\text { (3) }\end{array}$ & - & - \\
\hline Teratoma & - & $\begin{array}{l}04.22 \% \\
\text { (3) }\end{array}$ & - & $\begin{array}{l}01.41 \% \\
\text { (1) }\end{array}$ & - & - \\
\hline Yolk sac tumour & $\begin{array}{c}1.41 \% \\
(1)\end{array}$ & $\begin{array}{l}02.82 \% \\
\text { (2) }\end{array}$ & $\begin{array}{l}- \\
-\end{array}$ & $\begin{array}{l}02.82 \% \\
(2)\end{array}$ & - & - \\
\hline Total & 12 & 22 & 11 & 26 & - & - \\
\hline
\end{tabular}

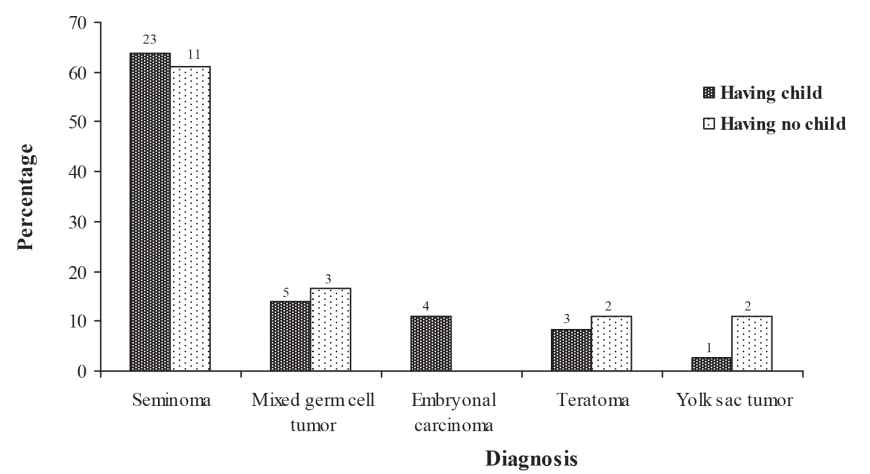

Fig. 1: Number and percentage of patients with and without children according to different types of testicular tumour.

\section{Site of origin of testicular tumour}

The tumour site of 87 patients was determined by the clinical reports. Of the 87 patients, 83 (95\%) had unilateral and 4
$(4.59 \%)$ had bilateral tumour. In unilateral tumour, the left side of the testis was commonly affected by the cancer in 36 (41.37\%), while right testicular cancers were found in 32 (36.78\%) subjects. There were 15 (17.24\%) patients whose record regarding the site of involved testis was not mentioned in their hospital clinical record; they were mentioned as unilateral (Table 3).

The highest number of patients was diagnosed with seminoma cancer stage II $(26.04 \%)$ followed by stage I $(17.70 \%)$ and the lowest number of patients was at stage III $(8.33 \%)$. In embryonal carcinoma, $3.12 \%$ of patients were at stage I, while at stage II and stage III, $7.29 \%$ and $1.04 \%$ of patients were observed, respectively. For teratoma tumour patients at stage I, stage II and stage III, the percentage of patients observed was $5.21 \%, 1.04 \%$ and $4.16 \%$, respectively. In mixed germ cell tumour, the number of patients at stage I was $7.29 \%$, at stage II, $8.33 \%$ and at stage III, 2.08\%. At stage I

Table 3: Number and percentage distribution of patients suffering from different types of testicular tumour on the basis of site of origin

\begin{tabular}{|c|c|c|c|c|c|}
\hline Diagnosis & $\begin{array}{c}\text { Left side } \\
\text { Percentage } \\
\text { (n) }\end{array}$ & $\begin{array}{l}\text { Right side } \\
\text { Percentage } \\
\text { (n) }\end{array}$ & 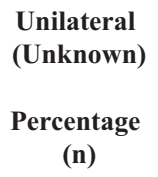 & $\begin{array}{c}\text { Bilateral } \\
\text { Percentage } \\
\text { (n) }\end{array}$ & $\begin{array}{c}\text { Total } \\
\text { n }\end{array}$ \\
\hline Seminoma & $\begin{array}{c}26.44 \\
(23)\end{array}$ & $\begin{array}{c}21.84 \\
(19)\end{array}$ & $\begin{array}{c}04.59 \\
\text { (4) }\end{array}$ & $\begin{array}{c}02.29 \\
(2)\end{array}$ & 48 \\
\hline Mixed germ cell tumour & $\begin{array}{c}09.19 \\
(8)\end{array}$ & $\begin{array}{c}02.29 \\
(2)\end{array}$ & $\begin{array}{c}03.44 \\
(3)\end{array}$ & $\begin{array}{c}01.14 \\
(1)\end{array}$ & 14 \\
\hline Embryonal carcinoma & $\begin{array}{c}02.29 \\
(2)\end{array}$ & $\begin{array}{c}04.59 \\
(4)\end{array}$ & $\begin{array}{c}02.29 \\
(2)\end{array}$ & $\begin{array}{c}01.14 \\
\text { (1) }\end{array}$ & 9 \\
\hline Teratoma & $\begin{array}{c}01.14 \\
\text { (1) }\end{array}$ & $\begin{array}{c}05.74 \\
(5)\end{array}$ & $\begin{array}{c}03.44 \\
\text { (3) }\end{array}$ & - & 9 \\
\hline Yolk sac tumour & $\begin{array}{c}02.29 \\
(2)\end{array}$ & $\begin{array}{c}02.29 \\
(2)\end{array}$ & $\begin{array}{l}03.44 \\
\text { (3) }\end{array}$ & - & 7 \\
\hline Total & $\begin{array}{c}41.37 \\
(36)\end{array}$ & $\begin{array}{c}36.78 \\
(32)\end{array}$ & $\begin{array}{c}17.24 \\
(15)\end{array}$ & $\begin{array}{c}04.59 \\
(4)\end{array}$ & 87 \\
\hline
\end{tabular}


and stage III in yolk sac tumour, 3.12\%, but at stage II, $2.08 \%$ of patients were observed (Fig. 2).

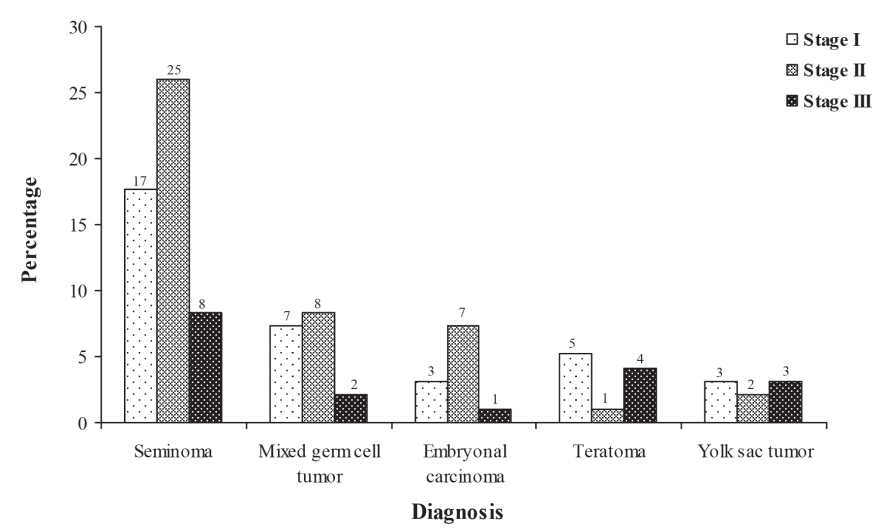

Fig. 2: Number and percentage of patients diagnosed with different types of testicular tumour according to stages of the disease.
Treatment for different types of testicular cancer

Patients diagnosed with different testicular tumour types were given courses of treatment such as chemotherapy, radiotherapy, both (chemotherapy and radiotherapy) and none (Table $4)$. Most patients were given both chemotherapy and radiotherapy treatment cycles. The majority of patients $(52 \%)$ with seminoma tumour received the drug regimen bleomycin, etoposide, cisplatin (BEP), but only $36.36 \%$ of patients with embryonal carcinoma received this drug regimen. Only patients with mixed germ cell tumours $(5.55 \%)$ and teratomas $(10 \%)$ received the etoposide and cisplatin (EP) drug regimen. Fourteen per cent of patients did not receive any drug treatment.

Treatments for testicular tumour types diagnosed at different stages are shown in Table 5. The highest number of average chemotherapy cycles $(3.5 \pm 0.63)$ was given at stage II for those with seminoma, while the lowest number of average chemotherapy cycles $(1.5 \pm 0.29)$ was given at stage II of

Table 4: Treatment regimens for patients with different types of testicular cancer

\begin{tabular}{|c|c|c|c|c|c|c|c|c|}
\hline \multirow{2}{*}{$\begin{array}{l}\text { Diagnosis } \\
\text { (n) }\end{array}$} & \multicolumn{4}{|c|}{ Mean cycles (n) } & \multicolumn{4}{|c|}{ Drugs (n) } \\
\hline & Chemotherapy & Radiotherapy & Both & None & BP & BEP & EP & NO \\
\hline $\begin{array}{l}\text { Seminoma } \\
\quad(50)\end{array}$ & $\begin{array}{c}2.77 \pm 0.44 \\
(18)\end{array}$ & $\begin{array}{c}1.75 \pm 0.48 \\
(4)\end{array}$ & $\begin{array}{c}6.58 \pm 0.73 \\
(24)\end{array}$ & (4) & $\begin{array}{l}32.00 \% \\
(16)\end{array}$ & $\begin{array}{l}52.00 \% \\
(26)\end{array}$ & - & $\begin{array}{c}16.00 \% \\
(8)\end{array}$ \\
\hline $\begin{array}{l}\text { Mixed germ cell tumour } \\
\text { (18) }\end{array}$ & $\begin{array}{c}1.67 \pm 0.24 \\
(5)\end{array}$ & - & $\begin{array}{c}6.18 \pm 1.23 \\
(11)\end{array}$ & (2) & $\begin{array}{l}27.77 \% \\
(5)\end{array}$ & $\begin{array}{l}55.55 \% \\
\quad(10)\end{array}$ & $\begin{array}{l}05.55 \% \\
\text { (1) }\end{array}$ & $\begin{array}{l}11.11 \% \\
\text { (2) }\end{array}$ \\
\hline $\begin{array}{l}\text { Embryonal carcinoma } \\
\text { (11) }\end{array}$ & $\begin{array}{c}3.00 \pm 1.00 \\
\text { (3) }\end{array}$ & - & $\begin{array}{c}8.00 \pm 1.62 \\
(7)\end{array}$ & (1) & $\begin{array}{l}54.54 \% \\
\text { (6) }\end{array}$ & $\begin{array}{l}36.36 \% \\
(4)\end{array}$ & - & $\begin{array}{l}09.09 \% \\
\text { (1) }\end{array}$ \\
\hline $\begin{array}{l}\text { Teratoma } \\
\qquad(10)\end{array}$ & $\begin{array}{c}2.25 \pm 1.25 \\
(4)\end{array}$ & - & $\begin{array}{c}6.40 \pm 1.44 \\
(5)\end{array}$ & (1) & $\begin{array}{l}20.00 \% \\
\text { (2) }\end{array}$ & $\begin{array}{l}60.00 \% \\
(6)\end{array}$ & $\begin{array}{l}10.00 \% \\
\text { (1) }\end{array}$ & $\begin{array}{c}10.00 \% \\
\text { (1) }\end{array}$ \\
\hline $\begin{array}{l}\text { Yolk sac tumour } \\
\text { (9) }\end{array}$ & $\begin{array}{c}1 \\
(1)\end{array}$ & $\begin{array}{c}1 \\
(1)\end{array}$ & $\begin{array}{c}8.50 \pm 4.20 \\
(6)\end{array}$ & (1) & - & $\begin{array}{c}77.77 \% \\
(7)\end{array}$ & - & $\begin{array}{c}22.22 \% \\
\text { (2) }\end{array}$ \\
\hline
\end{tabular}

BP: bleomycin and etoposide; BEP: bleomycin, etoposide and cisplatin; EP: etoposide and cisplatin; NO: no drugs

Table 5: Treatment regimens for patients with different types of testicular cancer according to stage of disease

\begin{tabular}{|c|c|c|c|c|c|c|c|c|c|c|c|c|c|c|c|}
\hline \multirow[t]{3}{*}{ Diagnosis (n) } & \multirow{3}{*}{\multicolumn{2}{|c|}{$\begin{array}{c}\text { Stage } \\
\text { (n) }\end{array}$}} & \multirow{2}{*}{\multicolumn{2}{|c|}{$\frac{\text { Mean cycles (n) }}{\text { Chemo }}$}} & & & & & & \multicolumn{6}{|c|}{ Drugs (n) } \\
\hline & & & & & \multicolumn{2}{|c|}{ Radio } & \multicolumn{2}{|l|}{ Both } & \multirow{2}{*}{$\begin{array}{c}\text { None } \\
(1)\end{array}$} & BP & \multicolumn{2}{|c|}{ BEP } & \multirow{2}{*}{$\begin{array}{r}\text { EP } \\
-\end{array}$} & \multicolumn{2}{|l|}{ NO } \\
\hline & & & $2.33 \pm 0.62$ & (9) & 3 & (1) & $3.83 \pm 0.70$ & (6) & & $23.52 \% \quad$ (4) & $64.70 \%$ & (11) & & $11.76 \%$ & (2) \\
\hline Seminoma & II & (25) & $3.50 \pm 0.63$ & (8) & 1 & (1) & $8.28 \pm 0.91$ & (14) & (2) & $40.00 \%$ (10) & $48.00 \%$ & (12) & - & $12.00 \%$ & (3) \\
\hline \multirow[t]{2}{*}{$(50)$} & III & (8) & 1 & (1) & $1.5=$ & $0.5(2)$ & $4.75 \pm 1.66$ & (4) & (1) & $25.00 \% \quad(2)$ & $37.50 \%$ & (3) & - & $37.50 \%$ & (3) \\
\hline & $\mathbf{I}$ & (7) & 2 & (1) & & - & $6.50 \pm 1.58$ & (6) & - & $57.14 \% \quad$ (4) & $42.85 \%$ & (3) & - & - & \\
\hline \multirow{3}{*}{$\begin{array}{l}\text { Mixed germ cell tumour } \\
\text { (17) }\end{array}$} & II & (8) & $1.50 \pm 0.29$ & (4) & & - & $4.50 \pm 2.18$ & (4) & - & $12.50 \% \quad(1)$ & $75.00 \%$ & (6) & - & $50.00 \%$ & (1) \\
\hline & III & (2) & - & & & - & 11 & (1) & (1) & - & $50.00 \%$ & (1) & - & $50.00 \%$ & (1) \\
\hline & I & (3) & $2.50 \pm 1.5$ & (2) & & - & 4 & (1) & - & $66.67 \% \quad(2)$ & $33.33 \%$ & (1) & - & - & \\
\hline \multirow{3}{*}{$\begin{array}{l}\text { Embryonal carcinoma } \\
\text { (11) }\end{array}$} & II & (7) & 4 & (1) & & - & $10.0 \pm 1.38$ & (5) & (1) & $57.14 \% \quad$ (4) & $28.57 \%$ & (2) & - & $14.28 \%$ & (1) \\
\hline & III & (1) & - & & & - & 3 & (1) & - & - & $100.0 \%$ & (1) & - & - & \\
\hline & I & (5) & 1 & (3) & & - & 2 & (1) & (1) & $40.00 \% \quad(2)$ & $40.00 \%$ & (2) & - & $20.00 \%$ & (1) \\
\hline \multirow{3}{*}{$\begin{array}{l}\text { Teratoma } \\
(10)\end{array}$} & II & (1) & 6 & (1) & & - & - & & - & - & $100.0 \%$ & (1) & - & - & \\
\hline & III & (4) & - & & & - & $7.5 \pm 1.19$ & (4) & - & - & $75.00 \%$ & (3) & $25 \%$ & (1) & \\
\hline & I & (3) & - & & & - & 2 & (2) & (1) & - & $66.66 \%$ & (2) & - & $33.33 \%$ & (1) \\
\hline \multirow{3}{*}{$\begin{array}{l}\text { Yolk sac tumour } \\
\text { (9) }\end{array}$} & & (2) & - & & 1 & (1) & 4 & (1) & - & - & $50.00 \%$ & (1) & - & $50.00 \%$ & (1) \\
\hline & III & (3) & 1 & (1) & & - & 7 & (2) & - & - & $100.0 \%$ & (3) & - & - & \\
\hline & NO & (1) & - & & & - & 29 & (1) & - & - & $100.0 \%$ & (1) & - & - & \\
\hline
\end{tabular}

BP: bleomycin and etoposide; BEP: bleomycin, etoposide and cisplatin; EP: etoposide and cisplatin; NO: no drugs 
mixed germ cell tumours. Stage II embryonal carcinoma had the highest number of average combined chemotherapy and radiotherapy cycles $(10 \pm 1.38)$; this was lowest $(3.83 \pm 0.70)$ for stage I seminoma. The majority of patients with stage II testicular tumour received the drug regimen BEP, while the lowest number of patients at stage III also received this drug regimen.

\section{Testosterone levels and blood cell count during chemother-} apy cycles

Testosterone levels before, during and after chemotherapy for patients diagnosed with different testicular tumours are shown in Table 6. Regression analysis of variance showed a significant $\left(\mathrm{b}=-0.5660 \pm 0.05725, \mathrm{~F}_{(1,2)}=97.75, p=0.0022\right)$ decrease in mean testosterone level during chemotherapy cycles, which returned to normal level after the completion of chemotherapy [six cycles] (Fig. 3).

Table 6: Testosterone levels (mean $\pm \mathrm{SE}$ ) in testicular tumour patients during different chemotherapy cycles

\begin{tabular}{lcc}
\hline Chemotherapy cycles & Testosterone level & (n) \\
\hline Before chemotherapy & $3.68 \pm 1.02$ & $(15)$ \\
After $1^{\text {st }}$ cycle & $2.93 \pm 0.36$ & $(12)$ \\
After $2^{\text {nd }}$ cycle & $2.33 \pm 0.63$ & $(10)$ \\
After $3^{\text {rd }}$ cycle & $1.67 \pm 0.58$ & $(10)$ \\
After $4^{\text {th }}$ cycle & $1.48 \pm 0.36$ & $(10)$ \\
After $6^{\text {th }}$ cycle & $3.80 \pm 0.29$ & $(18)$ \\
\hline
\end{tabular}

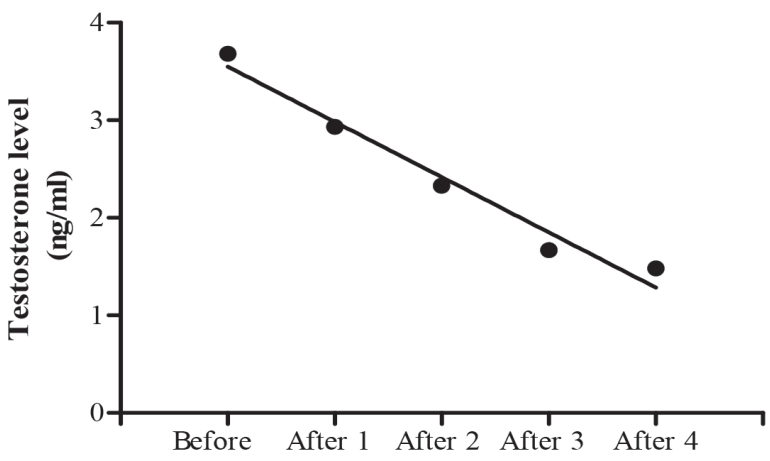

Che mothe rapy cycles

Fig. 3: Calculated regression line indicating decrease in testosterone level during different chemotherapy cycles.
The blood cell count in testicular tumour patients before, during and after chemotherapy cycles are shown in Table 7. A significant $\left(\mathrm{b}=-296.2 \pm 113.3, \mathrm{~F}_{(1,2)}=6.840, p=0.0474\right) \mathrm{de}-$ crease in mean white blood cells during different chemotherapy cycles was shown by regression analysis of variance (Fig. 4), but there was no significant ( $b=-0.08000 \pm 0.06239$,

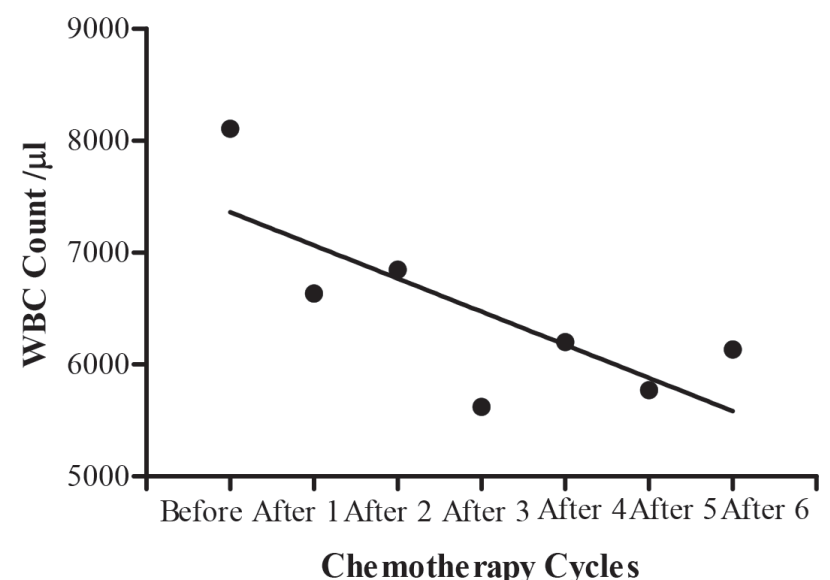

Fig. 4: Calculated regression line indicating decrease in while blood cell (WBC) count during different chemotherapy cycles.

$\left.\mathrm{F}_{(1,2)}=1.644, p=0.2560\right)$ decrease in haemoglobin level (Fig. 5). Regression analysis of variance showed a significant $\left(\mathrm{b}=-146300 \pm 56180, \mathrm{~F}_{(1,2)}=6.785, p=0.0480\right)$ decrease in

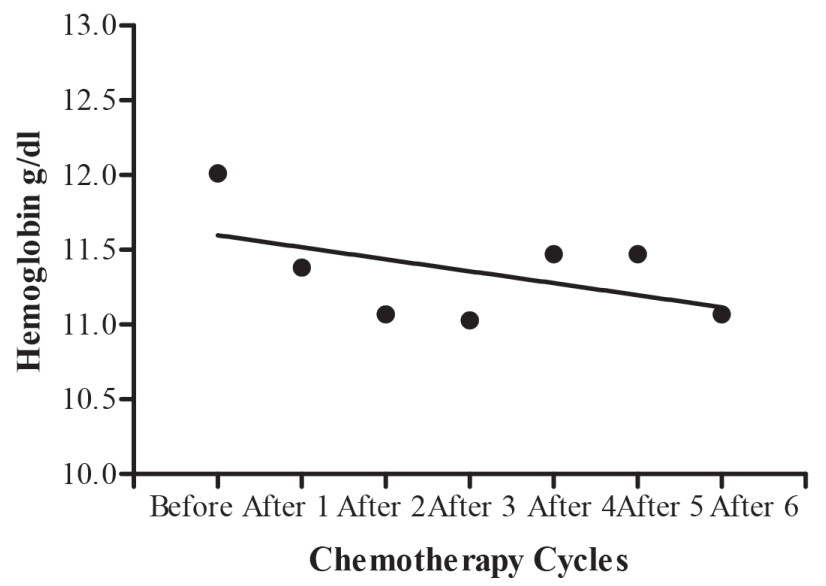

Fig. 5: Calculated regression line indicating no decrease in haemoglobin level during different chemotherapy cycles.

Table 7: Blood cell count (mean $\pm \mathrm{SE}$ ) in testicular tumour patients during different chemotherapy cycles

\begin{tabular}{lccccc}
\hline Chemotherapy cycles & (n) & WBC & RBC & HB & Platelets \\
\hline Before chemotherapy & $(76)$ & $8109.20 \pm 340.06$ & $4541974 \pm 084663.8$ & $12.01 \pm 0.24$ & $386378.4 \pm 88398.32$ \\
After 1 $1^{\text {st }}$ cycle & $(50)$ & $6633.40 \pm 560.16$ & $4308000 \pm 136046.8$ & $11.38 \pm 0.28$ & $349700.0 \pm 23462.30$ \\
After 2 $^{\text {nd }}$ cycle & $(43)$ & $6848.84 \pm 565.16$ & $4900233 \pm 084211.8$ & $11.07 \pm 0.27$ & $392907.0 \pm 32867.68$ \\
After 3 $3^{\text {rd }}$ cycle & $(35)$ & $5620.00 \pm 346.48$ & $3914571 \pm 084353.5$ & $11.03 \pm 0.26$ & $298857.1 \pm 27152.33$ \\
After 4 $^{\text {th }}$ cycle & $(28)$ & $6200.00 \pm 615.17$ & $3951429 \pm 077779.5$ & $11.47 \pm 0.22$ & $320500.0 \pm 33616.75$ \\
After 5 $^{\text {th }}$ cycle & $(24)$ & $5770.83 \pm 590.76$ & $3869167 \pm 136983.4$ & $11.47 \pm 0.44$ & $280416.7 \pm 19502.50$ \\
After 6 $^{\text {th }}$ cycle & $(14)$ & $6135.71 \pm 683.52$ & $3785000 \pm 1633793.5$ & $11.07 \pm 0.39$ & $226642.9 \pm 15497.11$ \\
\hline
\end{tabular}

WBC: white blood cell; RBC: red blood cell; HB: haemoglobin 
mean red blood cells during different chemotherapy cycles (Fig. 6). There was also a significant $\left(\mathrm{b}=-24650 \pm 5534, \mathrm{~F}_{(1}\right.$, 2) $=19.84, p=0.0067$ ) reduction in platelet cells during chemotherapy (Fig. 7).

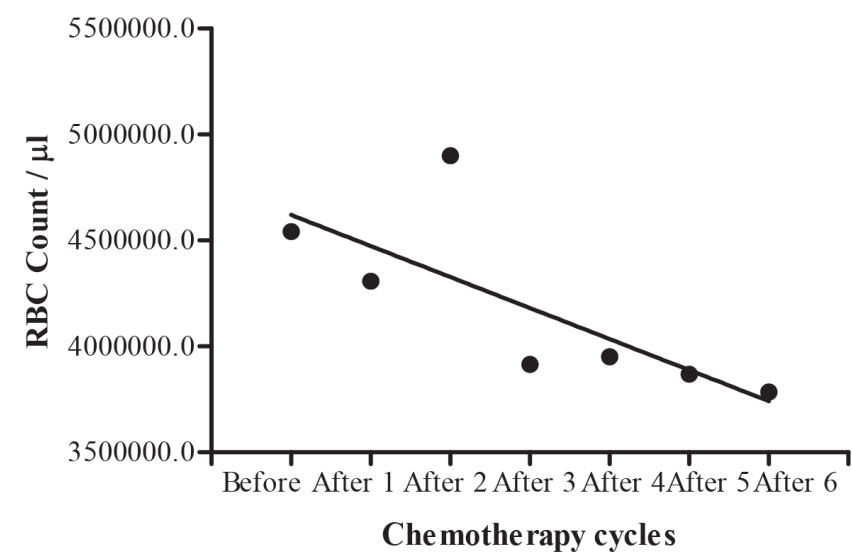

Fig. 6: Calculated regression line indicating decrease in red blood cell (RBC) count during different chemotherapy cycles.

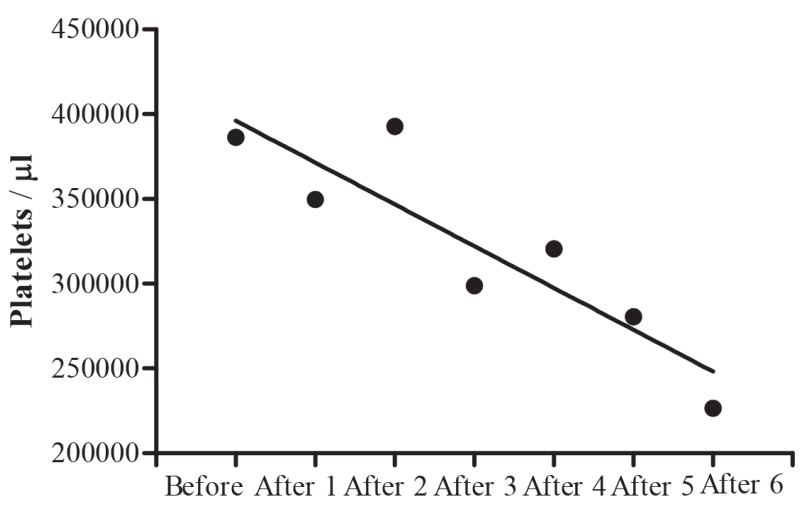

Che mothe rapy cycles

Fig. 7: Calculated regression line indicating decrease in platelet cells during different chemotherapy cycles.

\section{DISCUSSION}

The present study of 100 men with testicular cancer was conducted during 2011-2013. The age at diagnosis in the present study ranged from 1 to 70 years and mean age was $31.05 \pm$ 1.39 years. This finding is in confirmation with the study by Bhurgri et al from Hyderabad (Pakistan) who stated that the mean age for testicular cancer is 31.9 years, while the age range was 3 to 65 years (13). In another study, Raman et al reported that the mean age was 32.6 years and age range was 25 to 52 years (14). The peak incidence was observed at 2130 years in the present study, similar to the study by Naqvi et al from Nawabshah (Pakistan) who stated that testicular tumour patients were affected mostly in this age group (6).

For the histological classification of testicular cancer, clinical data presented an incidence of $50 \%$ for seminoma, which is similar to another report (15). No significant difference was observed between married and unmarried patients for risk of testicular cancer in the present study. In a study in London, it was also observed that there was no association between risk of cancers and marital status for ever versus never married (16). Most of the patients (67\%) with testicular cancers have children but not more than two or three. Similar findings were observed in two different stud-ies, Moller and Skakkbaek in Denmark and Baker et al, who reported in their study that those who have only one child or no children were at a greater risk of testicular cancers $(17,18)$. In another study conducted in Sweden, it was observed that increasing sibship size was associated with a reduced risk of testicular germ cell cancer (19). Almost one-third (31.71\%) of patients were diagnosed at stage I, which is contradictory to the study of Powles et al who described that the patients with stage I disease were more compared to other diagnosed stages and this was due to improved education and awareness of germ cell tumours, resulting in earlier diagnosis. The incidence of testicular cancer at stage I in seminoma was $17 \%$ and in nonseminoma it was $11 \%$ in the present study, similar to the study of Powles et al in the UK who observed that nonseminomas developed from seminomas (20). The mean age at stage I was highest as compared to other stages (II and III) in the present study. Regarding the site of origin of testicular tumour, bilateral tumours were observed in $4.59 \%$ patients at the time of diagnosis. Similar findings were observed in two different studies in which bilateral testicular germ cell tumours ranged between 1 and 5\%. Risk for bilateral germ cell tumours was low because when the unilateral tumour was diagnosed, it was treated by chemotherapy and radiotherapy; this resulted in a cure in most cases, with very low chances of developing a tumour in the contralateral testis $(21,22)$.

In the present study, the sera from 75 subjects were assayed before treatment, during different chemotherapy cycles and after the completion of chemotherapy cycles. It was observed that testosterone level was normal before receiving any treatment and it decreased during chemotherapy, but returned to normal level after chemotherapy treatment completion. Similarly, Gerl et al observed that testosterone levels decreased significantly in patients who received chemotherapy (23). While some studies reported that testosterone level was not any different between healthy men and those with testicular cancer (24), Meinardi et al reported that chemotherapytreated cancer patients had a significant increase in cardiac risk factors such as hyperlipidaemia, renal insufficiency, increased body mass index, hypertension and metabolic syndrome, and these may relate to hormonal changes, such as testosterone deficiency, caused by the combination of orchidectomy and chemotherapy treatment (25). Pectasides et al, as reported in a study in Greece, found that testosterone levels remained within the normal range after chemotherapy (26). The testosterone levels within normal range in patient groups indicate that high dose chemotherapy does not induce complete Leydig cell failure (27). 
Bleomycin, etoposide and cisplatin (BEP) chemotherapy was most commonly used for testicular patients in the current study and etoposide, cisplatin (EP) combination was used for few patients. A study conducted in Japan also found that BEP is the standard treatment option for testicular cancer due to low toxicities and high cure rate, while EP is used only for those patients whose disease was complicated by active asthma (28). Culine et al demonstrated that BEP and EP were both regimens used as standard of care in patients with a lower stage of disease (29).

In conclusion, most of the patients were diagnosed histologically as seminoma tumour. A larger number of patients was diagnosed at later stages of disease. Therefore, great effort is required to educate the population about self-examination and knowledge of the disease. Most of the patients received both chemotherapy and radiotherapy cycles and the most common drug regimen was BEP. This study demonstrates that testosterone level decreases during chemotherapy cycles, but returns to normal level after the completion of chemotherapy.

\section{REFERENCES}

1. Bray F, Richiardi L, Ekbom A, Pukkala E, Cuninkova M, Moller H. Trends in testicular cancer incidence and mortality in 22 European countries: continuing increase in incidence and decline in mortality. Int $\mathrm{J}$ Cancer 2006: 188: 3099-111.

2. Schmoll HJ, Souchon R, Krege S, Alberts P, Beyer J, Kollmannsberger C et al. European consensus on diagnosis and treatment of germ cell cancer: a report of the European Germ Cell Cancer Consensus Group (EGCCCG). Ann Oncol 2004; 15: 1377-99.

3. Dearnaley DP, Huddart RA, Horwich A. Managing testicular cancer. J Bio Med 2001; 322: 1583-8.

4. International Germ Cell Consensus Classification: a prognostic factorbased staging system for metastatic germ cell cancers. International Germ Cell Cancer Collaborative Group. J Clin Oncol 1997; 15: 594-603.

5. McGlynn KA, Devesa SS, Graubard BI, Castle PE. Increasing incidence of testicular germ cell tumours among black men in the United States. J Clin Oncol 2005; 23: 5757-61.

6. Naqvi SQH, Ansari AL, Memon NA, Memon JM, Akhund AA. Correlation of age with histopathological type of testicular tumors. Gomal J Med Sci 2006; 4: 24-7.

7. Dieckmann KP, Pichlmeier U. Clinical epidemiology of testicular germ cell tumors. World J Urol 2006; 22: 2-14.

8. McGlynn KA. Environmental and host factors in testicular germ cell tumors. Cancer Invest 2001; 19: 842-53.

9. Sharpe RM. The oestrogen hypothesis: where do we stand now? Inter J Androl 2003; 26: 2-15.

10. Jones WG, Fossa SD, Mead GM, Roberts JT, Sokal M, Horwich A et al. Randomized trial of 30 versus 20 Gy in the adjuvant treatment of stage I testicular seminoma: a report on Medical Research Council Trial TE18, European Organisation of Research and Treatment of Cancer Trial 30942 (ISRCTN1852532 8). J Clin Oncol 2005; 25: 1200-8.
11. Oliver RT, Mason M, Mead GM, von MH, Rustin GJS, Joffe JK et al. Radiotherapy versus single-dose carboplatin in adjuvant treatment of stage I seminoma: a randomized trial. Lancet 2005; 366: 293-300.

12. Wiechno P, Demkow T, Kubiak K, Sadowska M, Kaminska J. The quality of life and hormonal disturbances in testicular cancer survivors in cisplatin era. Eur Urol 2007; 52: 1454-5.

13. Bhurgri Y, Bhurgri A, Pervez S, Bhurgri M, Kayani N, Ahmed R et al. Cancer profile of Hyderabad, Pakistan 1998-2002. Asian Pacific J Cancer Prev 2005; 6: 474-80.

14. Raman D, Nobert CF, Goldstein M. Increased incidence of testicular cancer in men presenting with infertility and abnormal semen analysis. J Urol 2005; 175: 1819-22.

15. Jonathan I. The lower urinary tract and male genital system. In: Kumar V, Abbas AK, Fausto N, eds. Robbins and Cotran Pathologic Basis of Disease. $7^{\text {th }}$ ed. Philadelphia: Elsevier Saunders; 2005: 1037-44.

16. Aetiology of testicular cancer: association with congenital abnormalities, age at puberty, infertility and exercise. United Kingdom Testicular Cancer Study Group. BMJ 1994; 308: 1393-9.

17. Moller H, Skakkebaek NE. Risk of testicular cancer in subfertile men: case-control study. Bio Med J 1999; 318: 559-62.

18. Baker JA, Buck GM, Vena JE, Moysich KB. Fertility patterns prior to testicular cancer diagnosis. Cancer Causes Control 2005; 16: 295-9.

19. Richiardi L, Akre O, Lambe M, Granath F, Montgomery SM, Ekbom A. Birth order, sibship size and risk for germ-cell testicular cancer. Epidemiology 2004; 15: 323-9.

20. Powles TB, Bhardwa J, Shamash J, Mandalia S, Oliver T. The changing presentation of germ cell tumours of the testis between 1983 and 2002. BJU Int 2005; 95: 1197-1200.

21. Che M, Tamboli P, Ro JY, Park DS, Ro JS, Amato RJ et al. Bilateral testicular germ cell tumors: twenty year experience at the MD Andersen Cancer Center. Cancer 2002; 95: 1228-33.

22. Ohyama C, Kyan A, Satoh M, Saito S, Nishimura Y, Imai Y. Bilateral germ testicular tumors: a report of nine cases with long term follow up. Cancer 2002; 3: 173-7.

23. Gerl A, Muhlbayer D, Hansmann G, Mraz W, Hiddemann W. The impact of chemotherapy on Leydig cell function in long term survivors of germ cell tumors. Cancer 2001; 91: 1297-303.

24. Nord C, Bjoro T, Ellingsen D, Mykletun A, Dahl O, Klepp O. Gonadal hormones in long-term survivors 10 years after treatment for unilateral testicular cancer. Eur Urol 2003; 44: 322-8.

25. Meinardi MT, Gietema JA, van der Graaf WT, van Veldhuisen DJ, Runne MA, Sluiter WJ et al. Cardiovascular morbidity in long-term survivors of metastatic testicular cancer. J Clin Oncol 2000; 18: 1725-32.

26. Pectasides D, Pectasides M, Farmakis D, Nikolaou M, Koumpou M, Kostopoulou $\mathrm{V}$ et al. Testicular function in patients with testicular cancer treated with bleomycin etoposide and cisplatin $\left(\operatorname{bec}_{90}\right)$ combination chemotherapy. Eur Urol 2004; 45: 187-93.

27. Ishikawa T, Kamidono S, Fujisawa M. Fertility after high dose chemotherapy for testicular cancer. Urology 2004; 63: 137-40.

28. Kawai K, Ando S, Hinotsu S, Oikawa T, Sekido N, Miyanaga N et al. Completion and toxicity of induction chemotherapy for metastatic testicular cancer: an updated evaluation of Japanese patients. Japanese J Clin Oncol 2006; 36: 425-31.

29. Culine S, Kerbrat P, Kramar A, Theodore C, Chevreau C, Geoffrois L et al. Refining the optimal chemotherapy regimen for good-risk metastatic nonseminomatous germ-cell tumors: a randomized trial of the GenitoUrinary Group of the French Federation of Cancer Centers (GETUG T93BP). Ann Oncol 2007; 18: 917-24. 


\section{APPENDIX}

Data sheet

Laboratory evaluations and clinicopathological features of patients were recorded on the following data sheet.

$$
\text { Date - Reference No. }
$$

Patient profile

Subject name

Age at diagnosis

Presentation

Testicular swelling

Abdominal mass-

Family history

Close relative with cancer

Type of cancer-

Obstetric history

Marital status

Smoking-

No. of children

Past medical history

Undescended testis

Orchidectomy

Tuberculosis

Present medical history

Presenting complaints

Diagnostic procedure

\section{Present disease}

Stages

Bilateral

Treatment

Chemotherapy

Radiotherapy

Surgery

Histopathology hormone

Testosterone -

Blood picture

WBC

$\mathrm{HB}$
Hospital

Occupation

Present age

Pain in abdomen

Weight loss
Mumps in childhood

Hepatitis
Unilateral

Malignant

Drugs

Cycle

Follow up

$\mathrm{RBC}$

Platelets 